\title{
O Espiritismo é uma religião?
}

\section{A. Almeida Júnior}

Quando, em principios deste ano, exerciamos ainda o cargo de diretor do Ensino do Estado de São Paulo, fomos oficialmente solicitados no sentido de autorizar o ensino do espiritismo às crianças de uma escola primária. Os argumentos por nós aduzidos, na fundamentação do despacho que demos, parecem-nos de algum interesse júrídico, $e$, por isso, resolvemos transportá-los para estas páginas.

A Constituição Federal de 16 de Julho de 1934, - dissemos nós, - categórica no tocante à obrigatoriedade da admissão do ensino religioso nas escolas, dispunha:

Art. 153 -. O ensino religioso. constituirá matéria dos horários nas escolas públicas primárias, secundárias, profissionais e normais.

Menos imperativa, a Constituição de 10 de novembro de 1937 diz simplesmente:

Art. 133 - 0 ensino religioso poderá ser contemplado como matéria do curso ordinário das escolas primárias, normais e secundárias.

Continúa, porém, em vigor, no Estado de São Paulo, sem colidir, aliás, com a Constituição de 10 de novembro, o decreto n. 6.766 , de 11 de outubro de 1934 , que ordena às es- 
colas públicas facultar o ensino religioso, desde que solicitado pelos pais dos alunos:

Art. 12 - Fica incorporado ao regime escolar dos estabelecimentos oficiais de ensino primário, secundário, profissional e normal, o ensino religioso.

Isto posto, examinemos o caso presente.

O prof. Oscar Augusto Guelli, Delegado Regional do Ensino em Casa Branca, consulta, por ofício de 11 de fevereiro dêste ano, se deve atender a trinta e cinco pais de crianças matriculadas do Grupo Escolar de Itobí - pais êsses que desejam seja ministrado o ensino do Espiritismo a seus filhos.

Anteriormente à minha administração, o ensino do Espiritismo, considerado como religião, foi praticado no Grupo Escolar "Ruy Barbosa", de Caçapava, mas depois foi suspenso em virtude de incidentes a que deu causa. Em 1937, houve pedidos de autorização, nessa mesma localidade, assim como em duas outras cidades do interior, tendo sido todos negados por se haverem apresentado fóra da época legal.

A atual solicitação, encaminhada pelo sr. Delegado Regional de Casa Branca, está dentro do prazo regulamentar e atende aos requisitos formais estipulados pelo decreto paulista n. 6.766, e pelas "Instruções" da Diretoria do Ensino.

Cumpre, no entretanto, decidir uma questão preliminar: é o Espiritismo uma religião?

Sem entrar no delicado têma da conceituação filosófica de "religião", faremos notar que nas religiões, em geral, o objeto para o qual se volta o espírito humano é o sobrenatural, o mistério:

"Qualquer conceito de religião envolve um processo de relações vitais entre a criatura humana e o sobrenatural" (Alfred Bertholet, Encyclopedia of the Social Sciences). 
Demais, a fórma pela qual o homem recebe as verdades religiosas é, inicialmente, a revelação, e, secundariamente, a persuasão, que se dirige de preferência à personalidade afetiva; mantendo-se essas verdades no espírito humano em virtude da crença, alicercada na fé. Por isso, o conteúdo subjetivo das religiões é de fundo preponderantemente afetivo e modestamente cognitivo. Por isso, ainda, como assevera Georges Dumas (Traité de Psychologie, II, 208), todas as Igrejas sempre protestaram contra a subordinação da fé ao raciocínio.

O'ra, o Espiritismo, no dizer dos seus mestres, foge do sobrenatural e do mistério.

"Não existe o sobrenatural", diz Camille Flammarion junto à sepultura de Allan Kardec. O Espiritismo "é o fim do sobrenatural e do milagre", declara outro iniciado (LÉoN Denis, No Invisivel, trad. de L. Cirne, Rio 1909, pag. 27).

Para o próprio Allan Kardec, o Espiritismo vem mostrar o mundo espiritual,

"não mais como coisa sobrenatural, porém, ao contrário, como uma das fôrças vivas e sem cessar atuantes da natureza, como a fonte de uma imensidade de fenômenos até hoje incompreendidos e, por isso, relegados para o domínio do fantástico e do maravilhoso" ( $O$ Evangelho segundo o Espiritismo, trad. de G. RibeIro, 24. ${ }^{\mathrm{a}}$ ed., Rio, 1938).

Vê-se, pois, que, ao contrário das religiões, o Espiritismo recusa o sobrenatural e o milagre.

Os métodos por êle preconizados não são os das religiões e sim os da ciência: o Espiritismo gloria-se de adotar a observação e a experiência, e acha que vem sendo "formado gradualmente por sucessivas observações" (Allan KARDEc, Trabalho, Perseverança, Solidariedade, trad. port., 8. ${ }^{a}$ ed., Rio, 1935, pag. 361). Como a Física ou a Química, "a ciência espirita compreende duas partes: uma experimental. 
e outra filosófica" (0 mesmo autor, Livros dos Espíritos, pag. XLVI).

O Espiritismo (sempre no dizer dos seus autores) estuda a alma humana pelos mesmos processos por que CLAUDE BERNARD estudou as funções do fígado: através da observação e da experiência:

“De meio século para cá, o estudo da alma passou do domínio da metafísica e do mero conceito, ao da experiência e da observação" (LÉoN Denis, op. cit., pagina 19).

Mas o que é muito mais categórico do que tudo isso é a atitude dos mestres do Espiritismo, quando reclamam expressamente para o seu corpo de doutrina o epíteto de ciência. Ouça-se Allan Kardec, nestas passagens em que, come nas subsequentes, grifamos as palavras mais significativas:

"O Espiritismo é a ciência nova que vem revelar aos homens, por meio de provas irrecusaveis, a existência e a natureza do mundo espiritual e as suas relações com o mundo corpóreo" (O Evangelho segundo o Espiritismo, pag. 5).

“Assim tem sido até hoje com o espiritismo. Formado gradualmente por sucessivas observações, como todas as ciências. " (Trabalho, Solidariedade, Perseveranç, pag. 361).

"Depois de havermos exposto no "Livro dos Espíritos" a parte filosófica da ciência espirita, damos nesta obra a parte prática" (Livro dos Mediuns, 7." ed. port., Rio, 1914, pag. VIII).

“O Espiritismo, que alcança graves questões de filosofia, em todos os ramos da ordem social, que abrange ao mesmo tempo o homem físico e o homem moral, é, só por si, uma ciência, uma filosofia, que não póde ser aprendida em horas, 
como não o póde ser qualquer outra ciência" (Idem, ib., pag. 13).

Essa a opinião insuspeita de Allan Kardec: o Espiritismo é uma ciência. Não menos afirmativo se mostra LÉoN Denis :

"Faça ela (a ciência francesa) do Espiritismo uma ciência nova, que complete as outras ciências" (Op. cit. pag. 38).

"Dos estudos espíritas uma nova ciência se vai formando lentamente" (Op. cit., pag. 7).

"Em seu conjunto, todos êsses fatos constituem já uma nova ciência, baseada no método positivo" (Op. cit. pag. 26).

"O Espiritismo é a ciência do além-tumulo" (Op. cit. pag. 30).

"A essa filosofia, a essa ciência, livre, independente, emancipada de toda pressão oficial, de todo compromisso político, as descobertas contemporâneas trazem cada dia novas e preciosas contribuições" (Mesmo autor, O Problema do Sêr e do Destino, trad. port., Rio, 1910, pagina 16).

O proprio autor do "Contrato Social", chamado do outro mundo a opinar, diz textualmente (sob a fé dos espiritas que o invocaram e que lhe propagam as palavras), numa definição que tanto serve para o Espiritismo como para a psicanálise de Freud:

"Creio que o Espiritismo é um estudo completamente filosófico das causas secretas, dos movimentos interiores da alma, pouco definidos até agora" (Comunicação de além-túmulo de J. J. Rousseau, in Livro dos Mediuns, pag. 439).

O Espiritismo, como se vê, procura insinuar-se no quadro das ciências. Ciência que, como as demais, recusa o sobrenatural e o mistério; ciência positiva, que apela para o 
raciocinio e não para a fé; que quer prescrutar a natureza através da observação e da experiência; que, evitando a cristalização, o acabado das doutrinas religiosas, espera desenvolver-se e aperfeiçoar-se à custa do estudo. Tudo isso se opõe a que tanto os iniciados como os adversários e até os indiferentes possam considerá-lo uma religião.

Por isso, Camille Flammarion pôde dizer, no seu já mencionado discurso à beira da sepultura de Allan Kardec:

"O Espiritismo não é uma religião, e sim uma ciência, da qual mal conhecemos o $a, b$, c."

Por isso, ainda, o Espiritismo, em lugar de "templos" em que o coração dos fieis se entrega sem reservas ao poder sobrenatural de Deus e se impregna dos seus mistérios, possue sucursais mais ou menos idôneas de associações como a "Society for Psychical Research", laboratórios, "científicos" em que o cérebro dos "estudiosos" se aplica, em atitude de crítica, na observação de "mesas girantes", na catalogação dos "barulhos espontâneos", nas investigações sôbre o perispírito e os "espíritos glóbulos", na análise das evocações, na interpretação dos fatos de "xenoglóssia" ou de "mediunidade animal".

Pouco importa que os espíritas também divulguem e pratiquem certos princípios normativos da conduta humana, extraídos da moral leiga ou da religião: êssas noções de empréstimo são para êle tão acessórias como o juramento hipocrático o é para as ciências médicas, ou como a ética profissional dos advogados para as ciências jurídicas.

“A religião só teria a ganhar em autoridade se acompanhasse o progresso dos conhecimentos científicos" (G. Melusson, Iniciação no Espiritismo, trad. port., de G. Ribeiro, sem data, Rio, pag. 23).

E nessa situação voluntariamente procurada, de estudo científico que deseja ser imparcial, objetivo, "livre, indepen- 
dente, emancipado", isento de noçõ̀es preconcebidas, inimigo do sobrenatural e do mistério, o Espiritismo espera que um dia todas as igrejas o adotem, como doutrina neutra capaz de convir a quaisquer religiões:

"Aceito e aconselhado por todas as igrejas (G. Melusson, op. cit., pag. 23).

Por não ser uma religião - como se acaba de demonstrar, quer pela análise dos seus caracteres fundamentais, quer pelo propósito expresso dos seus arautos - o Espiritismo não pode reclamar as prerrogativas facultadas pelı art. 133 da Constituição Federal e asseguradas pelo decreto paulista n. 6.766, de 11 de outubro de 1934. Poderá, se entender conveniente, pleitear, como "ciência do além-túmulo", o seu ingresso na secção de Ciências Físicas e Naturais da Universidade. Porque, si no dizer de Allan Kardec, $(O$ Evangelho Segundo o Espiritismo, pagina 15), o seu estudo exige "maturidade mental", o Espiritismo não está ao alcance da inteligência das crianças de sete a quatorze anos, que frequentam a escola primária. 